Int. J. Odontostomat.,

12(3):327-331, 2018.

\title{
Juvenile Xanthogranuloma: A Case Report and Review of the Literature
}

\author{
Xantogranuloma Juvenil: Informe de un Caso y Revisión de la Literatura
}

Divya Raj ${ }^{1}$ \& R. Rathy²

RAJ, D. \& RATHY, R. Juvenile xanthogranuloma: A case report. Int. J. Odontostomat., 12(3):327-331, 2018.

SUMMARY: Juvenile xanthogranuloma (JXG), is a benign histiocytic proliferation of uncertain histiogenesis which was first described by Adamson in 1905. It is a regressing disorder which occurs in children usually within first year of life. A child of ten months age reported to the Azeezia College of Dental Sciences and Research with a nodular swelling on the right side of the cheek and gave a history of swelling since the age of 5 months with gradual increase in size which was not associated with pain or itching. A provisional diagnosis of Haemangioma was made and excision biopsy of the lesion was done under general anaesthetia. Depending on the histopathologic and immunohistochemical findings a diagnosis of Juvenile Xanthogranuloma was made. The excisional biopsy site healed uneventfully with minimal scar formation. JXG is a benign fibrohistiocytic lesion and a type of granulomatous process. Pathogenesis of the lesion is unknown. It is generally considered to be a reactive lesion. Most common presentation is as solitary cutaneous lesion. Children are affected at a median age of 2 years with a male female ratio of 1.5:1. Classic histopathologic findings include Nodular to diffuse collection of histiocytes with finely vacuolated foamy cytoplasm and round to oval nuclei, Touton giant cells which are the cells with a central wreath of nuclei and peripheral rim of eosinophilic to vacuolated cytoplasm loaded with fat and Inflammatory infiltrate such as lymphocytes and eosinophils. JXG has to be clinically differentiated from Xanthoma, Molluscum contagiosum, Haemangioma and Neurofibroma. Mostly a self-limiting disease which spontaneously resolves. Conservative management is the treatment of choice. Excision may be done due to esthetic and diagnostic reasons. Recurrence is uncommon. JXG is a disease predominantly of early childhood, benign and self-healing.

KEY WORDS: Juvenile xanthogranuloma, case report.

\section{INTRODUCTION}

Juvenile xanthogranuloma (JXG), is a benign histiocytic proliferation of uncertain histiogenesis which was first described by Adamson in 1905 (Cypel \& Zuker, 2008). JXG is characterized by red to yellow cutaneous nodules located mainly on the head and neck area (Gianotti \& Caputo, 1985). It is a regressing disorder which occur in children usually within first year of life (Jung et al., 2000). It is histologically characterized by the presence of a dermal histiocytic infiltrate, with high lipid content and accumulation of multinucleated giant cells, known as Touton giant cells. Here we report a case of 10 month year old boy with JXG localized to right side of the cheek and the literature is reviewed.

\section{CASE REPORT}

A child of ten months age reported to the Azeezia College of Dental Sciences and Research with a nodular swelling on the right side of the cheek and gave a history of swelling since the age of 5 months with gradual increase in size which was not associated with pain or itching. There was no history of trauma. The medical history was noncontributaory. Patient consulted a dermatologist for the same and attempted cauterization of the lesion.

On local examination there was a well circumscribed round nodular errythematous swelling of size $0.5 \times 0.5 \mathrm{~cm}$ with a central depression on the

\footnotetext{
${ }^{1}$ Assistant Professor, Dental Division, Regional Cancer centre, Trivandrum, Kerala, India.

${ }^{2}$ Professor Department of Oral Pathology and Microbiology Azeezia, College of Dental Sciences and Research, Kollam, Kerala, India.
} 
right side of the cheek $2 \mathrm{~cm}$ behind the right commissure of lip (Fig. 1). On palpation the lesion was firm in consistency. A provisional diagnosis of Haemangioma was made and excision biopsy of the lesion was done under general anaesthetia (GA).

Gross appearance of the lesion was creamish white in color, oval in shape, firm in consistency of size $1 \times 0.8 \mathrm{~cm}$ (Fig. 2). The histological evaluation revealed spindle shaped fibroblastic cells with numerous foamy histiocytes and multiple Tuton giant cells. Inflammatory infiltrate are also seen (Fig. 3).

\section{Immunohistochemical analysis was done using} CD68, CD34 and Vimentin. CD68 and Vimentin were strongly positive and CD34 was negative (Figs. 4, 5 and 6). Depending on the histopathologic and immunohistochemical findings a diagnosis of Juvenile Xanthogranuloma was made. The excisional biopsy site healed uneventfully with minimal scar formation.

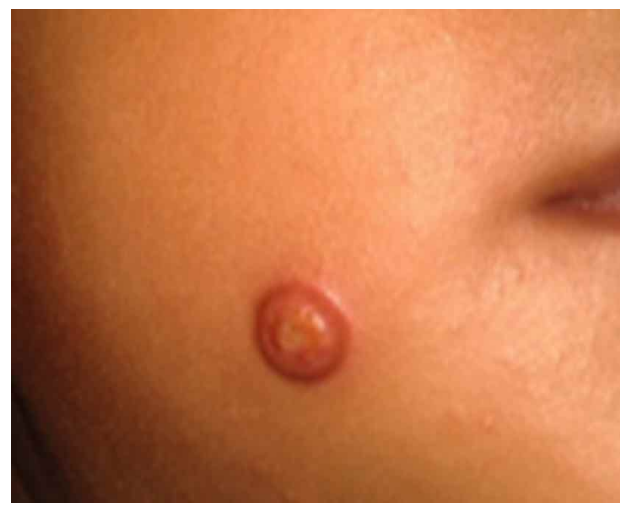

Fig. 1. Lesion located on the right side of the cheek.

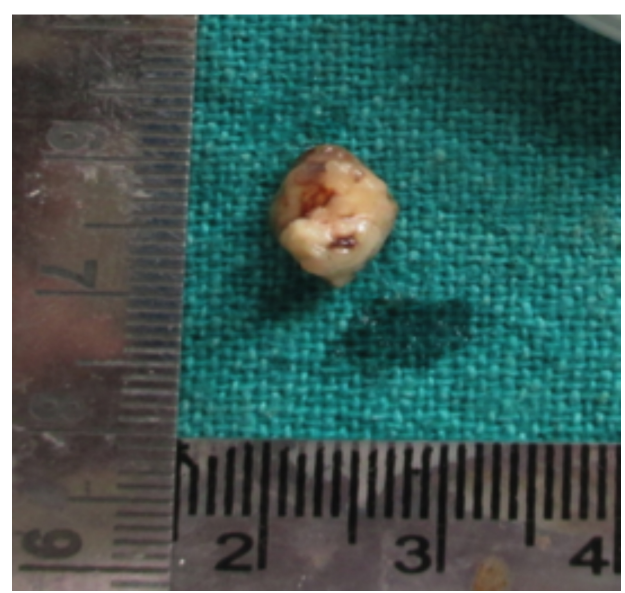

Fig. 2. Biopsy of the lesion extracted under general anaesthetic (GA).

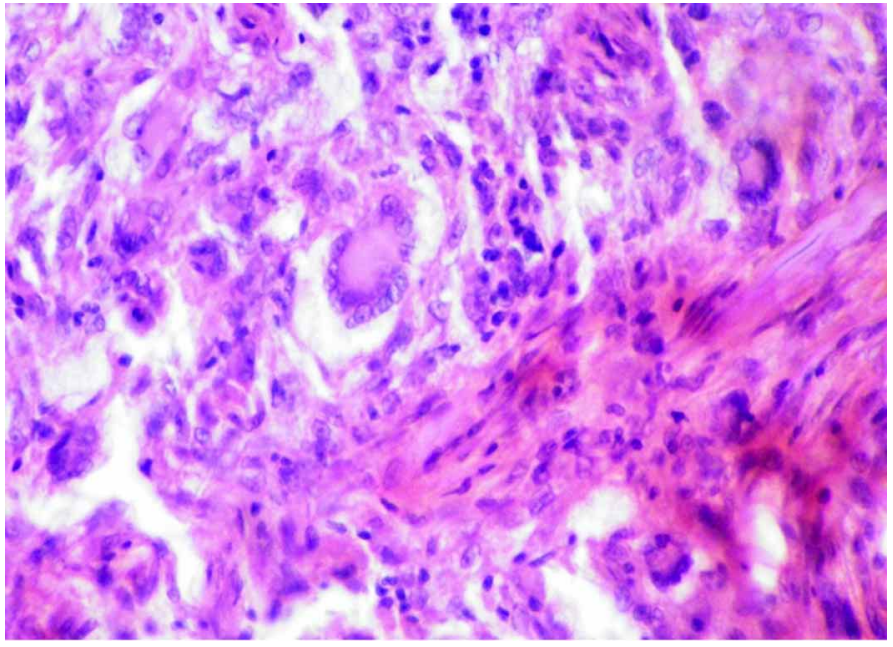

Fig. 3. Haematoxyllin and eosin stain.

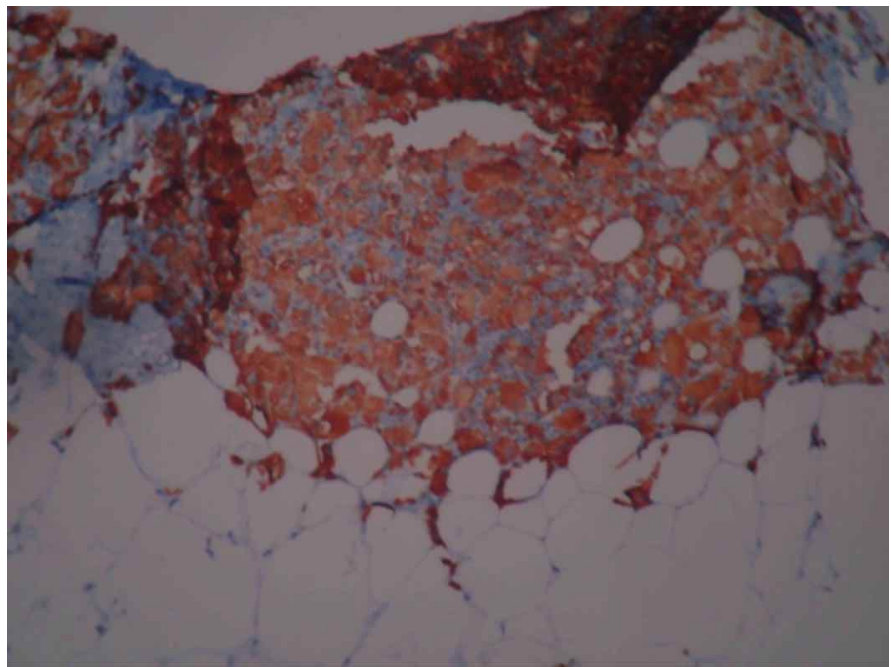

Fig. 4. CD68 immunohistochemical analysis.

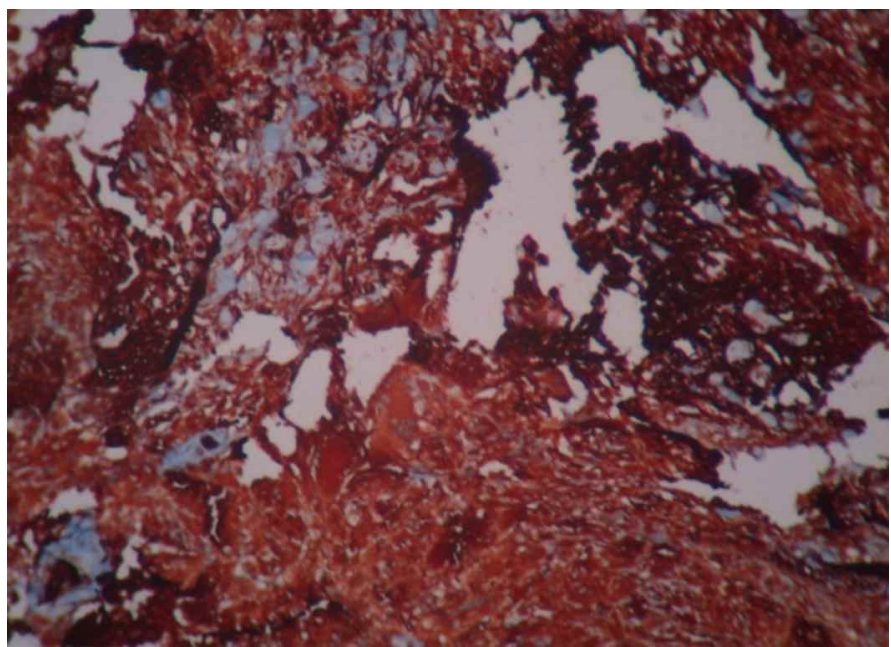

Fig. 5. Vimentin immunohistochemical analysis. 


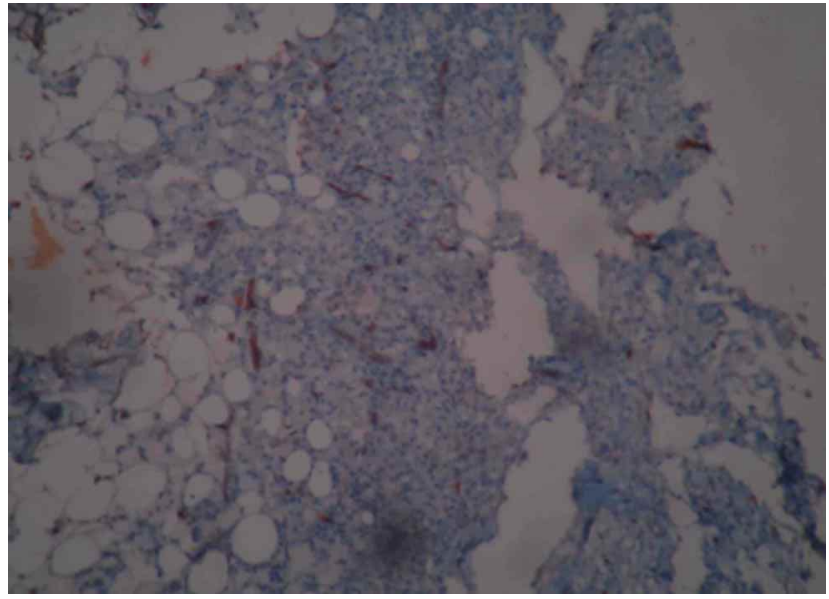

Fig. 6. CD34 immunohistochemical analysis.

\section{DISCUSSION}

JXG is a benign fibrohistiocytic lesion and a type of granulomatous process, at time accompanied by lipid deposition (Cypel \& Zuker). Histiocytes are diverse group of cells which includes fixed and mobile macrophages and immune accessory cells which orginate from bone marrow precursor or blood monocyte (Foucar \& Foucar, 1990). The term histiocytosis denotes benign and malignant diseases characterized by proliferation of histiocytic cells (Table I).

Adamson in 1905 coined the term congenital Xanthoma Multiplex for single or multiple cutaneous nodules in infancy. In 1912 Mc Donagh described these lesions as Nevoxanthoendothelioma. Helwing and Hackney in 1954 coined the term Juvenile Xantho Granuloma (Helwing \& Hackney, 1954).

Pathogenesis of the lesion is unknown. It is generally considered to be a reactive lesion derived from monocyte or macrophage in response to unknown etiologic agent either physical or infectious (Sangüeza et al., 1995; Zelger et al., 1996; Hernandez-Martin et al., 1997).
Most common presentation is as solitary cutaneous lesion (Cohen \& Hood, 1989; Chang et al., 2001). It can also present as soft tissue lesion with or without organ involvement. JXG may be localized to single anatomic site organ or soft tissues without skin lesions or it can occur as multiple organ involvement with cutaneous or subcutaneous lesions (Chang, 1999; Cauro et al., 2002). Main visceral locations are lung, bone, testis, gastrointestinal tract, heart, eye, and oral cavity (Cusik \& Spicer, 1994; Lesniak et al., 2002; Margulis et al., 2003). Oral lesions are rare 31 microscopically documented oral lesions have been previously reported in English literature. In ocular involvement, the most frequent forms of presentation are uveitis, irritation and photophobia.

Cutaneous lesions are the most common clinical presentation. Children are affected at a median age of 2 years with a male female ratio of 1.5:1. However, children with multiple lesions tend to be younger with average age 5 months and a much higher rate of occurrence in boys with male: female ratio of $12: 1$ (Dehner, 2003). Size of the lesion can vary. Most of the cases skin lesions are Papule or Nodule which are errythematous or yellowish in color with size less than $1 \mathrm{~cm}$ (Caputo et al., 1998). According to the size of the lesion Gianotti distinguished two forms of presentation. Micronodular form: less than $10 \mathrm{~mm}$ in size, multiple lesions. Macronodular form: size between 10 and 20 $\mathrm{mm}$. Macronodular form is associated with systemic lesions. Common site for cutaneous lesions are head and neck regions.

The second most common clinical presentation are subcutaneous or deep soft tissue mass. Fifty percent of cases occur in the Head and neck region. Thirty five percent of cases were diagnosed in infants below the age of three months. JXG can also occur in association with systemic diseases such as neurofibromatosis type I and juvenile chronic myelogenous leukemia (Hernandez-Martin et al.; lyengar et al., 1998).

Table I. Classification of histiocytic tumor in children.

\begin{tabular}{|c|c|c|}
\hline Class I & Class II & Class III \\
\hline \multirow[t]{6}{*}{ Langerhans cell histiocytosis } & Mononudear phagocytes other than Langerhans cells & Malignant histiocytic disorders \\
\hline & $>\quad$ Haemophagocytic lymphocytosis & $>$ Acute monocytic leukemia \\
\hline & $>$ Infection associated lymphocytic syndrome & $>\quad$ Malignant histiocytosis \\
\hline & $>$ Sinus histiocytosis with massive & $>$ True histiocytic \\
\hline & $>\quad$ Juvenile xanthögranuloma & $>\quad$ lymphoma \\
\hline & Reticulocytoma & \\
\hline
\end{tabular}




\section{Histopathologic features}

Classic histopathologic findings include nodular to diffuse collection of histiocytes with finely vacuolated foamy cytoplasm and round to oval nuclei, Touton giant cells which are the cells with a central wreath of nuclei and peripheral rim of eosinophilic to vacuolated cytoplasm loaded with fat and Inflammatory infiltrate such as lymphocytes and eosinophils.

There are three characteristic histologic patterns: early JXG (EJXG), classic JXG (CJXG), and transitional JXG (TJXG) (Janssen \& Harms, 2005). Early JXG consists of histiocytes with little or no lipid infiltration, lymphocytes and eosinophils. In Classic JXG histiocytes are vacuolated, due to lipid deposition and Touton giant cells appear at this stage. In Transitional JXG fibrosis occurs and there is spindle shaped cells resembling benign fibrous histiocytoma.

\section{Immunohistochemistry}

Markers for tissue macrophages CD68 and HAM56 are valuable tools in the diagnosis of JXG (Janney et al., 1991; Shapiro et al., 1991). Factor XIIla cells are specialized macrophages and have role in immune response and tissue repair. Histiocytes of JXG belongs to this group of Macrophages and so JXG shows Factor XIlla positivity (Derrick et al., 1993). S100 will be negative in JXG which helps to differentiate it from Histiocytosis X (Fartasch et al., 1990).

\section{Differential diagnosis}

JXG has to be clinically differentiated from Xanthoma, Molluscum contagiosum, Haemangioma and Neurofibroma. Mode of distribution of the lesion and absence of lipid abnormalities exludes xanthoma. Molluscun contagiosum are dome shaped papule with a central umbilication. Neurofibromas are associated with cafeaulait spots (Kesavan \& Sreedevi, 2005).

Various histopathologic differential diagnosis includes Langerhans cell histiocytosis (LCH), Benign fibrous histiocytoma (BFH), Xanthomas, Reticulohistiocytoma. In LCH the lesional cells are langerhans cell, Touton giant cells are absent, Birbeck granules seen in electron microscopy, CD1a, S100 are positive. CD68 and Factor XIIla are negative. In BFH there will be Storiform appearance, Thick collagen fibers, Hyperplastic epidermis, Varying number of inflammatory cells and Factor XIIla, CD34 are Positive .There will be Uniform proliferation of foam cells and
Touton giant cells will be absent in Xanthomas. Large cells with glassy cytoplasm and randomly arranged nuclei together with histiocytes and fibroblast are seen in Reticulohistiocytoma but those are absent in JXG.

\section{Treatment and prognosis}

Mostly selflimiting disease which spontaneously resolve. lesions may completely resolve or there may be a residual scar. Conservative management is the treatment of choice. Excision may be done due to esthetic and diagnostic reasons. Recurrence is uncommon. In case of systemic involvement chemotherapy and radiotherapy may be required. The prognosis is usually good. Systemic juvenile xanthogranuloma may be life-threatening.

\section{CONCLUSION}

JXG is a disease predominantly of early childhood, benign and self-healing. An adequate multidisciplinary follow-up is needed to identify the extracutaneous involvement and its complications. To establish an accurate diagnosis microscopic evaluation and immunohistochemical staining are necessary.

RAJ, D. \& RATHY, R. Xantogranuloma Juvenil: Informe de un Caso y Revisión de la Literatura. Int. J. Odontostomat., 12(3):327-331, 2018.

RESUMEN: El xantogranuloma juvenil (JXG) es una proliferación histiocítica benigna de histiogénesis incierta que fue descrita por primera vez por Adamson en 1905. Es un trastorno regresivo que ocurre en los niños generalmente durante el primer año de vida. Un niño de diez meses de edad consultó al Colegio de Ciencias e Investigación Dental Azeezia por la presencia de hinchazón nodular en el lado derecho de la mejilla y un historial de hinchazón desde la edad de 5 meses con un aumento gradual en el tamaño que no estaba asociado con dolor o comezón. Se realizó un diagnóstico provisional de hemangioma y se realizó una biopsia de escisión de la lesión con GA. A partir de los hallazgos histopatológicos e inmunohistoquímicos, se realizó un diagnóstico de Xantogranuloma Juvenil. El sitio de la biopsia por escisión se curó sin incidentes con una formación de cicatriz mínima. JXG es una lesión fibrohistiocítica benigna y un tipo de proceso granulomatoso. La patogenia de la lesión es desconocida. Generalmente se considera que es una lesión reactiva. La presentación más común es como una lesión cutánea solitaria. Los niños se ven afectados a una edad media de 2 años con una proporción de hombres y mujeres de 1,5:1. Los hallazgos histopatológicos clásicos incluyen 
colección nodular a difusa de histiocitos con citoplasma espumoso finamente vacuolado y núcleos redondos a ovalados, células gigantes de Touton que son las células con una corona central de núcleos y margen periférico de citoplasma eosinófilo a vacuolado cargado con grasa e infiltrado inflamatorio como linfocitos y eosinófilos. JXG tiene que ser clínicamente diferenciado de Xanthoma, Molluscum contagiosum, Hemangioma y Neurofibroma. Es una enfermedad principalmente autolimitante que se resuelve espontáneamente. El tratamiento conservador es el tratamiento de elección. La escisión puede realizarse por razones estéticas y diagnósticas. La recurrencia es poco común. JXG es una enfermedad predominantemente de la primera infancia, benigna y autocurable.

\section{porte de caso.}

PALABRAS CLAVE: Xantogranuloma juvenil, re-

\section{REFERENCES}

Caputo, R.; Cambiaghi, S.; Brusasco, A. \& Gelmetti, C. Uncommon clinical presentations of juvenile xanthogranuloma. Dermatology, 197(1):45-7, 1998.

Cauro, R.; Houtteville, J. P.; Mesnil, J. L. \& Guarnieri, J. Cerebellar, pulmonary and cutaneous localizations of juvenile xanthogranuloma. Ann. Dermatol. Venereol., 129(3):307-10, 2002.

Chang, M. W. Update on juvenile xanthogranuloma: unusual cutaneous and systemic variants. Semin. Cutan. Med. Surg., 18(3):195-205, 1999.

Chang, S. E.; Cho, S.; Choi, J. C.; Choi, J. H.; Sung, K. J.; Moon, K. C. \& Koh, J. K. Clinicohistopathologic comparison of adult type and juvenile type xanthogranulomas in Korea. J. Dermatol., 28(8):413-8, 2001.

Cohen, B. A. \& Hood, A. Xanthogranuloma: report on clinical and histologic findings in 64 patients. Pediatr. Dermatol., 6(4):262-6, 1989.

Cusik, E. L. \& Spicer, R. D. Juvenile xanthogranuloma with extracutaneous lesions--a case report. Eur. J. Pediatr. Surg., 4(6):3689, 1994.

Cypel, T. K. \& Zuker, R. M. Juvenile xanthogranuloma: case report and review of the literature. Can. J. Plast. Surg., 16(3):175-7, 2008.

Dehner, L. P. Juvenile xanthogranulomas in the first two decades of life: a clinicopathologic study of 174 cases with cutaneous and extracutaneous manifestations. Am. J. Surg. Pathol., 27(5):57993, 2003.

Derrick, E. K.; Barker, J. N.; Khan, A.; Price, M. L. \& Macdonald, D. M. The tissue distribution of factor XIIla positive cells. Histopathology, 22(2):157-62, 1993.

Fartasch, M.; Vigneswaran, N.; Diepgen, T. L. \& Hornstein, O. P. Immunohistochemical and ultrastructural study of histiocytosis $X$ and non-X histiocytoses. J. Am. Acad. Dermatol., 23(5 Pt. 1):885-92 1990.

Foucar, K. \& Foucar, E. The mononuclear phagocyte and immunoregulatory effector (M-PIRE) system: evolving concepts. Semin. Diagn. Pathol., 7(1):4-18, 1990.

Gianotti, F. \& Caputo, R. Histiocytic syndromes: a review. J. Am. Acad. Dermatol., 13(3):383-404, 1985.

Helwing, E. B. \& Hackney, V. C. Juvenile xanthogranuloma. Am. J. Pathol., 30:625-6, 1954.
Hernandez-Martin, A.; Baselga, E.; Drolet, B. A. \& Esterly, N. B. Juvenile xanthogranuloma. J. Am. Acad. Dermatol., 36(3 Pt. 1):355-67, 1997.

lyengar, V.; Golomb, C. A. \& Schachner, L. Neurilemmomatosis, NF2, and juvenile xanthogranuloma. J. Am. Acad. Dermatol., 39(5 Pt. 2):831-4, 1998.

Janney, C. G.; Hurt, M. A. \& Santa Cruz, D. J. Deep juvenile xanthogranuloma. Subcutaneous and intramuscular forms. Am. J. Surg. Pathol., 15(2):150-9, 1991.

Janssen, D. \& Harms, D. Juvenile xanthogranuloma in childhood and adolescence: a clinicopathologic study of 129 patients from the kiel pediatric tumor registry. Am. J. Surg. Pathol., 29(1):21-8, 2005.

Jung, T.; Emmert, S.; Günzl, H. J.; Neumann, C. \& Rünger, T. M. Congenital manifestations of juvenile xanthogranuloma (large nodular form). Hautarzt, 51(6):423-6, 2000.

Kesavan, T. M. \& Sreedevi, P. K. Juvenile xanthogranuloma. Indian Pediatr., 42(9):950, 2005.

Lesniak, M. S.; Viglione, M. P. \& Weingart, J. Multicentric parenchymal xanthogranuloma in a child: case report and review of the literature. Neurosurgery, 51(6):1493-8, 2002.

Margulis, A.; Melin-Aldana, H. \& Bauer, B. S. Juvenile. Juvenile xanthogranuloma invading the muscles in the head and neck: clinicopathological case report. Ann. Plast. Surg., 50(4):425-8, 2003.

Sangüeza, O. P.; Salmon, J. K.; White, C. R. Jr. \& Beckstead, J. H. Juvenile xanthogranuloma: a clinical, histopathologic and immunohistochemical study. J. Cutan. Pathol., 22(4):327-35, 1995.

Shapiro, P. E.; Silvers, D. N.; Treiber, R. K.; Cooper, P. H.; True, L. D. \& Lattes, R. Juvenile xanthogranulomas with inconspicuous or absent foam cells and giant cells. J. Am. Acad. Dermatol., 24(6 Pt. 1):1005-9, 1991.

Zelger, B. W.; Sidoroff, A.; Orchard, G. \& Cerio, R. Non-Langerhans cell histiocytoses. A new unifying concept. Am. J. Dermatopathol., 18(5):490-504, 1996.

\section{Corresponding author:}

Dr. Divya Raj, MDS

Assistant professor

Dental Division

Regional Cancer Centre

Trivandrum

Kerala

INDIA

Email: dr.divyaabi@gmail.com

Received: 26-06-2018

Accepted: 09-07-2018 